\title{
Reactivity of 1,2,3-triazole-substituted 1-azabutadienes (vinamidines)
}

\author{
Sándor Bátori, ${ }^{\mathrm{a}, \mathrm{b}}{ }^{\dagger \dagger}$ Sándor Bokotey, and András Messmer ${ }^{\mathrm{b}}$ \\ ${ }^{a}$ Chinoin Private Co, Ltd., P.O.Box 110, Budapest, H-1325, Hungary \\ ${ }^{b}$ Chemical Research Center, Hungarian Academy of Sciences, P.O.Box 17, Budapest, H-1525, \\ Hungary \\ E-mail: sandor.batori@amriglobal.com
}

Dedicated to Prof. Ferenc Fülöp on the occasion of his $60^{\text {th }}$ birthday

\begin{abstract}
The reactivity of the new 1,2,3-triazole-substituted vinamidines (i.e. 1-azabutadienes) was investigated. They were used as synthons to obtain new pyrazole, di-1,2,3-triazole as well as 4amino-1,2,3-triazole derivatives. The Diels-Alder reaction with inverse electronic demand (using dimethyl 1,2,4,5-tetrazin-3,6-dicarboxylate as reagent) resulted in the formation of a new pyridazine derivative.
\end{abstract}

Keywords: 1-Azabutadiene, vinamidine, 1,2,3-triazole, reduction of vinamidines, cycloaddition, Diels-Alder reaction

\section{Introduction}

The vinamidines and vinamidinium salts are valuable synthons in the synthesis of a variety of new compounds. ${ }^{2-4}$ We studied the reactivity of two new 1-azadienes (1a,b), described by us recently. ${ }^{1}$ These vinamidines were found to be fairly stable under the conditions of their preparation, although their aminolysis or hydrolysis could theoretically lead to the formation of aminotriazole 2. This compound was isolated in low yield as byproduct in the reaction that gave 1b. ${ }^{1}$

\section{Results and Discussion}

In order to study the possibility of formation of $\mathbf{2}$, the 1 -azadiene $\mathbf{1 b}$ was reacted with an excess of morpholine in the presence of morpholinium perchlorate. A slow reaction took place at room 
temperature and instead of the expected aminotriazole $\mathbf{2}^{1}$ (which was isolated in very low, $2 \%$ yield), two other products were obtained: the 2-bromo-2-propenal-3-yl-aminotriazole $\mathbf{3}^{1}$ (37\%; being formed via the hydrolysis of the morpholine moiety) and the 3-hydroxy-4-morpholino-1aza-1,3-butadien-1-yl derivative 4 (29\%; being formed by the hydrolysis of the bromo substituent).

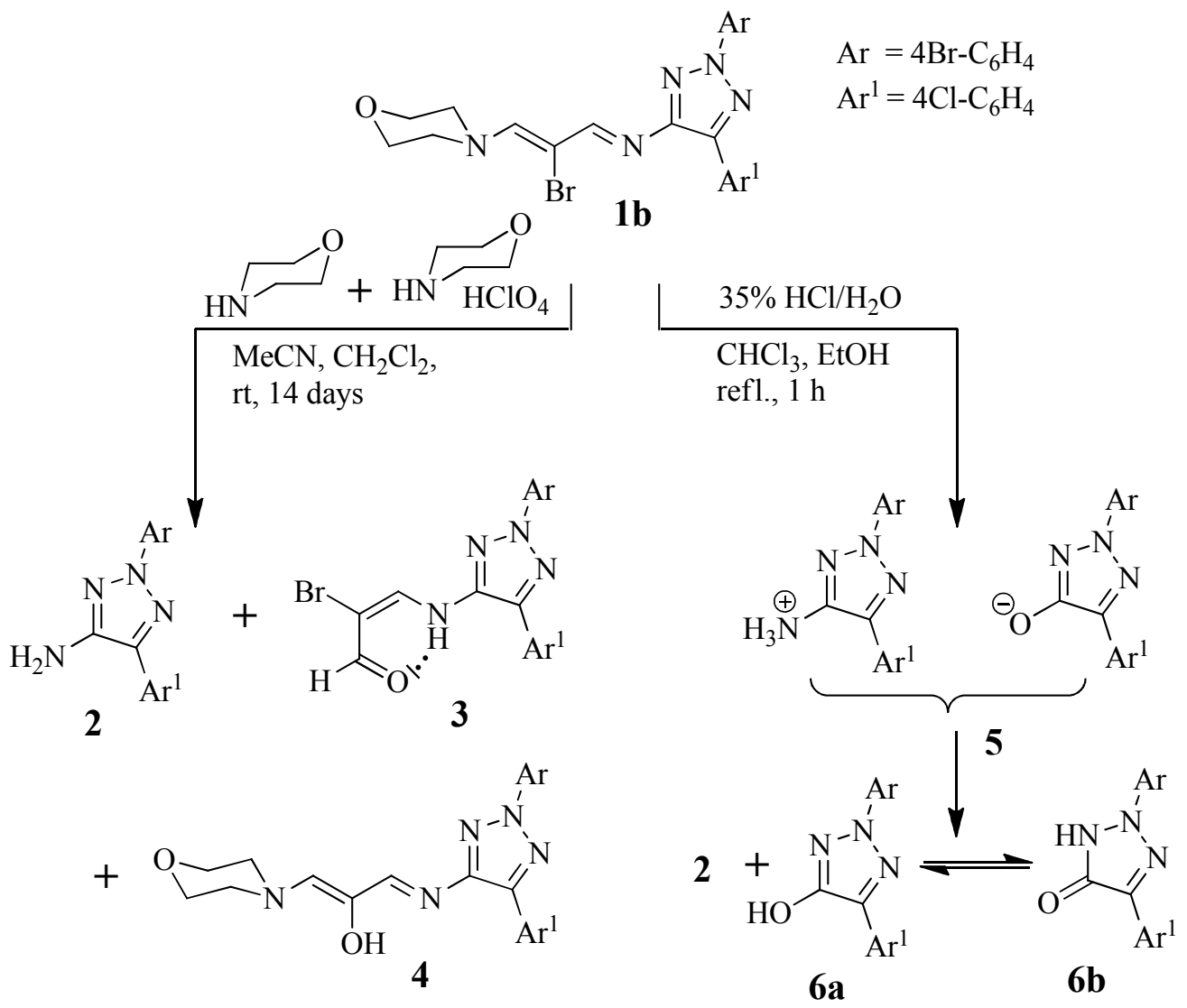

Scheme 1. Aminolysis and hydrolysis of vinamidine 1b.

The structure elucidation of $\mathbf{4}$ showed that depending on the solvent it can also exist in zwitterionic form. The acidic hydroxy group at position 3 can protonate the $\mathrm{N}$-atom at position 1 (or the $\mathrm{N}$-atom of the morpholine substituent). As a result, the nitrogen atom in question became positively charged, while the oxygen was bearing a negative charge.

The reaction with morpholine showed that the aminolysis of $\mathbf{1 b}$ was not a favoured process to give 2, instead the hydrolysis of the morpholino or the bromo substituents took place under influence of traces of water in the solvent.

Under acidic conditions at room temperature the vinamidine $\mathbf{1 b}$ is stable. At reflux temperature, however, the reaction of $\mathbf{1 b}$ with aq. $\mathrm{HCl}$ resulted in (within $1 \mathrm{~h}$ ) a yellow crystalline product. Its structure elucidation showed that the resulted compound (5) has a salttype character and contains the protonated amine (2) and the hydroxytriazole anion $\mathbf{6}$ in $1: 1$ 
ratio. The two components were separated by column chromatography to give the pure $\mathbf{2}$ as well as $\mathbf{6}$. This exists in equilibrium of two tautomeric forms, $\mathbf{6 a}$ and $\mathbf{6 b}$, the latter being the dominant form (IR: $1644 \mathrm{~cm}^{-1}$ ).

On the other hand, a successful aminolysis (hydrazinolysis) took place when the 1-azadiene 1b was reacted with 4-bromophenylhydrazine: the aminotriazole 2 was obtained in $67 \%$ yield. The other product, isolated in excellent yield (81\%), was 4-bromo-1-(4-bromophenyl)pyrazole (7) ${ }^{5}$. This compound was synthesized earlier by bromination of 1-phenylpyrazole or 1-(4bromophenyl)pyrazole ${ }^{5,6}$ and 4-bromo-1-phenylpyrazole. ${ }^{7} \mathrm{~W}$. Dieckmann and L. Platz ${ }^{8}$ studied the reaction of chloro- and bromomalonaldehyde with aniline. They isolated 3-chloro- (or 3bromo)-1-phenyl-4-(phenylamino)-1-azadienes. The reaction of these vinamidines with phenylhydrazine gave 4-chloro- (or 4-bromo)-1-phenylpyrazoles. The reaction, found by us, represents a modification of this method to produce 4-substituted pyrazoles.

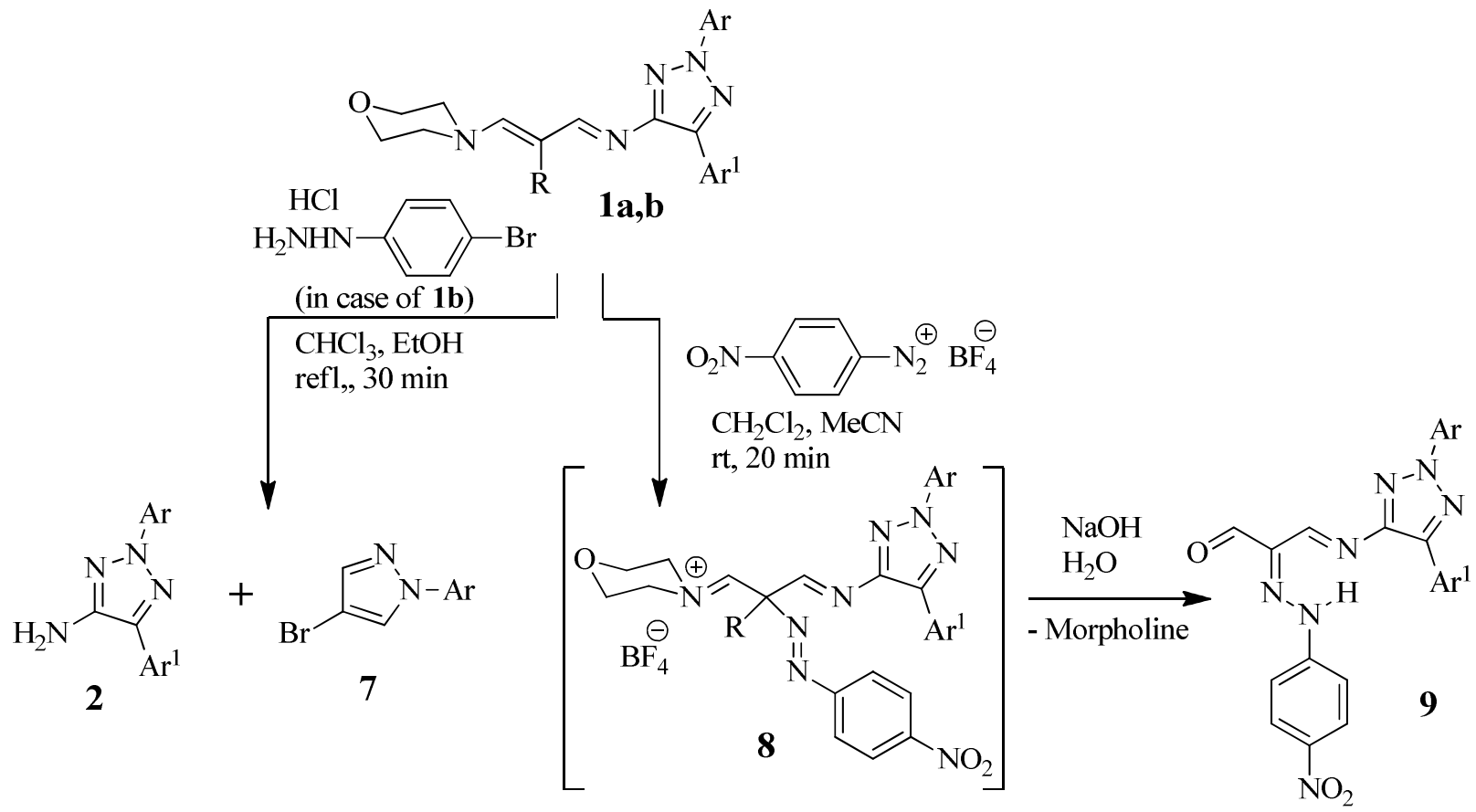

Scheme 2. Reaction of vinamidines 1a,b with 4-bromophenylhydrazine and 4-nitrophenyldiazonium fluoroborate.

The reaction of 1a with 4-nitrobenzenediazonium fluoroborate resulted in an unstable, insoluble orange solid as crude product (having very probably the structure 8), that after work up with aq. $\mathrm{NaOH}$ (hydrolysis of the morpholino group) and chromatography, gave the hydrazone 9 (in $83 \%$ yield). It is interesting that the vinamidine $\mathbf{1 b}$ gave the same hydrazone $\mathbf{9}$ (but in much lower yield) as was isolated in the case of 1a. In this case, the aminotriazole $\mathbf{2}$ was formed as byproduct in comparable yield to 9 . 
Interestingly, some hetaryl substituted dienamines ${ }^{9}$ reacted with aryldiazonium salts similarly to vinamidines $\mathbf{1 a , b}$ with formation of hydrazones, while 2 -azadiene compounds ${ }^{10}$ resulted in the formation of 1,2,4-triazole derivatives.

The reduction of vinamidines 1a with tetrabutylammonium borohydride or sodium borohydride gave, as expected, the morpholinopropylamine derivative $\mathbf{1 0}$ as major product in $51 \%$ yield.

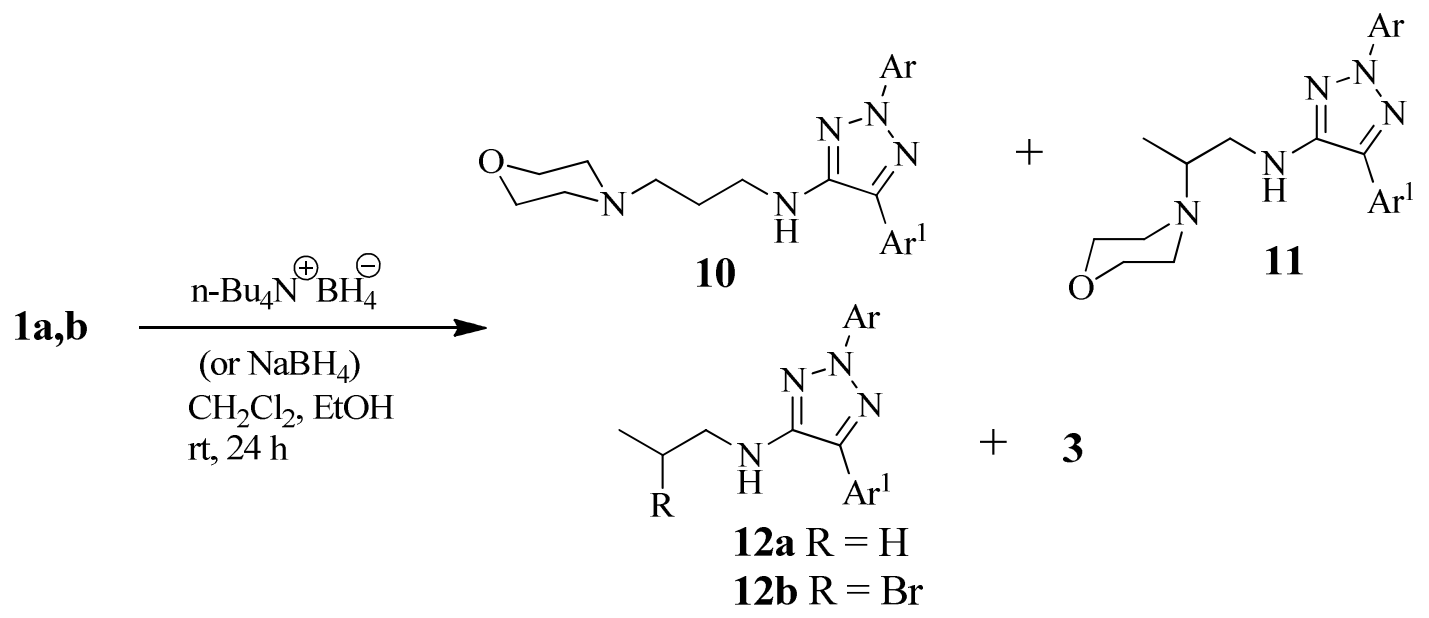

Scheme 3. Reduction of vinamidines 1a,b with borohydride.

Similar reactions are described in the literature: Ch. Jutz et al. ${ }^{11}$ carried out the reaction of vinamidines and vinamidinium salts with $\mathrm{NaBH}_{4}$ to get 1,3-diaminopropane derivatives, while W. Schroth et al. ${ }^{12}$ reduced vinamidines catalytically on $\mathrm{Pd} / \mathrm{C}$ to get similarly 1,3diaminopropane derivatives.

In the case of $\mathbf{1 b}$ the isomeric derivative $\mathbf{1 1}$ was also obtained. Its formation can be explained by the reduction of the intermediate aziridinium salt $\mathbf{1 4}$ (Scheme 4), which was formed by an intramolecular attack of the nitrogen atom of morpholine on the $\beta$-C-atom of the first intermediate (13) of the reduction. As minor products of the reduction, propylamines 12a,b were also isolated.

$\mathbf{1 b}$
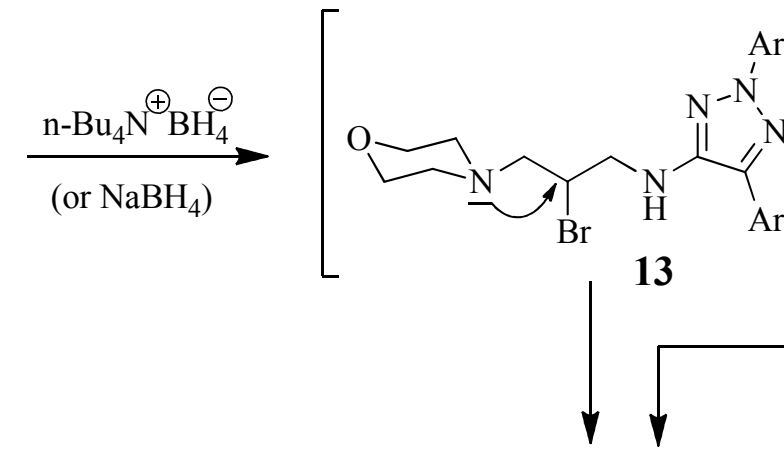

10

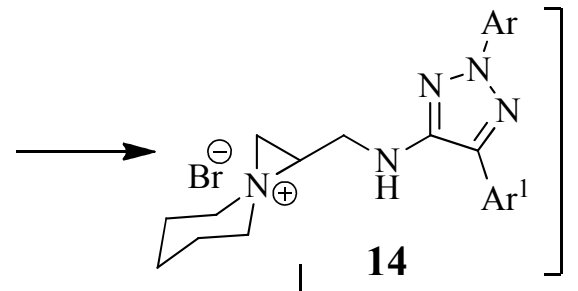

14

Scheme 4. Formation of isomeric morpholinopropylamine derivative 11. 
The ring opening of activated (like 14) and non-activated aziridines is widely studied. S. Stankovic et al. ${ }^{13}$ gave a detailed overview in a recent review about the regioselectivity found in the reaction of 2-substituted aziridines with nucleophiles (see also citations therein). The reaction is dependent on the activation and the nucleophile used. Usually the reaction occurs at the more hindered $\mathrm{C}$-atom when the nucleophile is halogen (except fluoride), azide, and cyanide ion. Alcohols ${ }^{14}$ and hydride anion ${ }^{15}$ prefer the less hindered $\mathrm{C}$-atom.

We found that the 1-azadienes $\mathbf{1 a , b}$ did not react with $N$-phenylmaleinimide even at elevated temperature if heated for longer time (Scheme 5). The compound $\mathbf{1 b}$ didn't react with dimethyl acetylenedicarboxylate at ambient temperature. After prolonged heating at $100{ }^{\circ} \mathrm{C}$ a multicomponent mixture was formed, from which no definite product could have been isolated.

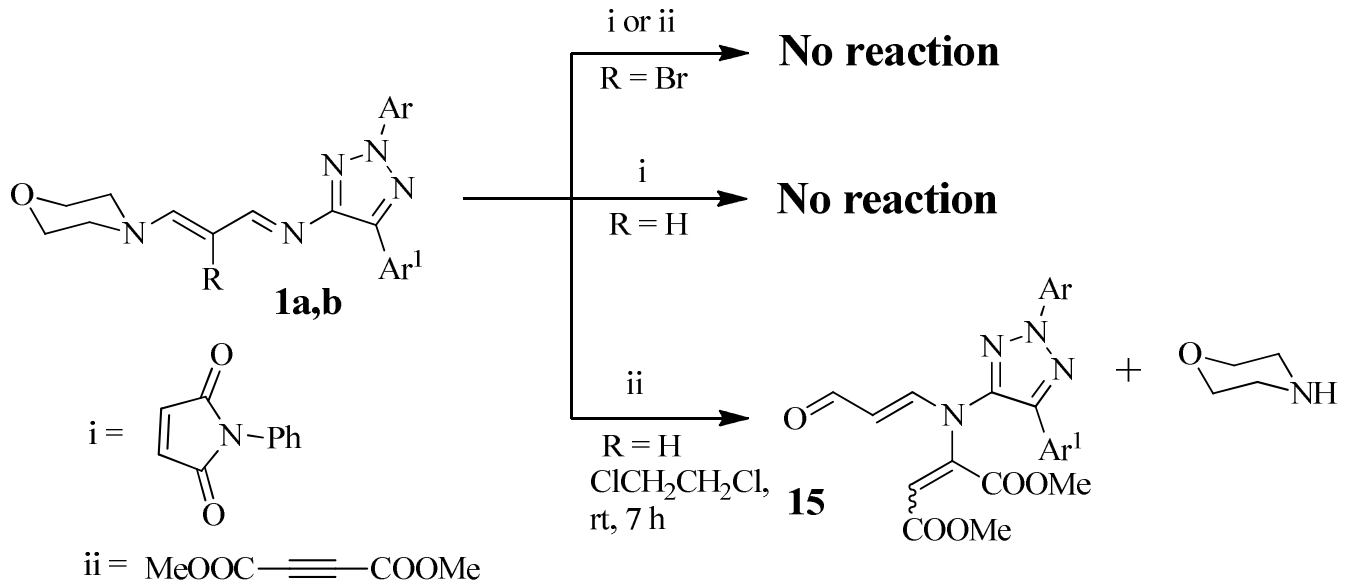

Scheme 5. Attempted Diels-Alder reactions of vinamidines 1a,b.

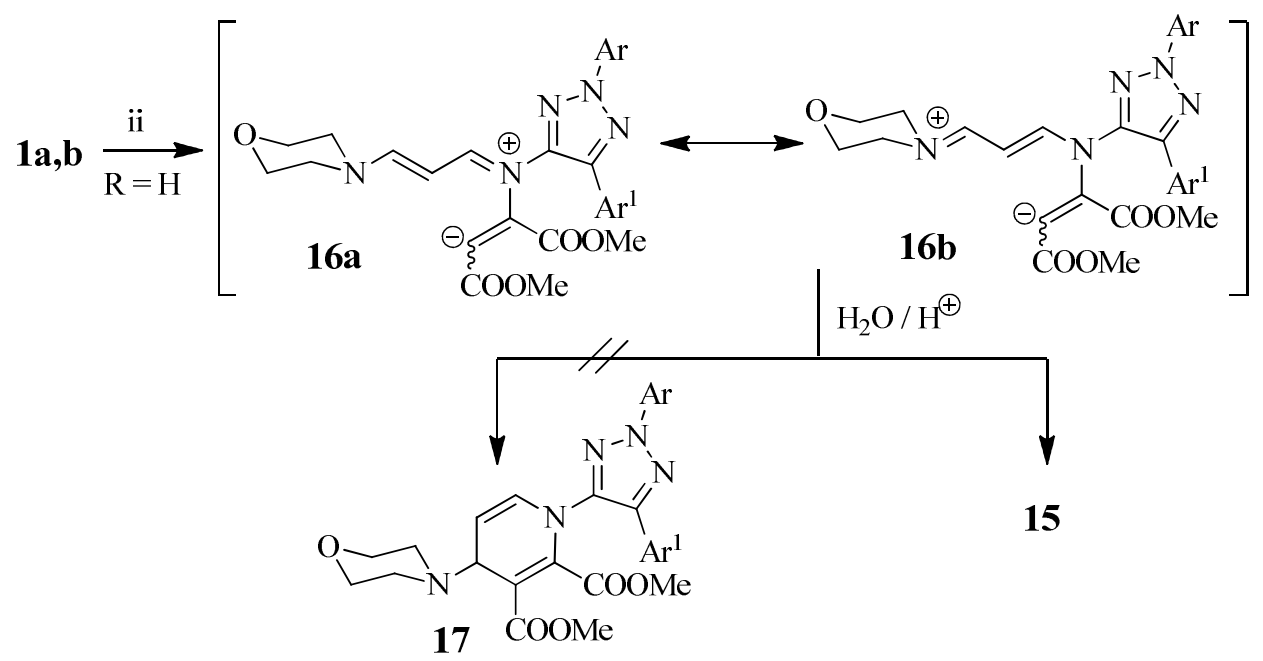

Scheme 6. Intermediates in the formation of $\mathbf{1 5 .}$ 
The less electrondeficiant aminoazabutadiene 1a, however, did react with dimethyl acetylenedicarboxylate but instead of a cycloadduct (17), compound 15 was isolated in low (37\%) yield. Its formation can be explained by the hydrolysis of the first intermediate (16a and 16b) of the addition (see Scheme 6). According to the ${ }^{1} \mathrm{H}$ NMR the configuration of the doublebond of the propenal moiety of $\mathbf{1 5}$ is trans $\left({ }^{3} J_{\mathrm{HH}}=13.4 \mathrm{~Hz}\right)$, while the configuration of the doublebond of the diester could not be determined.

The reaction of $\mathbf{1 b}$ with 4-toluenesulfonyl azide (18) led to the formation of $\mathbf{1 9}$ in low (15\%) yield (Scheme 7). The isolation of this compound was important because it provides a proof for the reaction mechanism of this type of reactions. Earlier it was found ${ }^{16}$ that the reaction of related systems, the aminobutadiens with 4-toluenesulfonyl azide (18) led to the formation of triazole- or tetrazole-substituted pyrazoles. An intermediate similar to 23 (Scheme 8) was postulated in that reaction, from which $\mathrm{N}$-(4-toluenesulfonyl)morpholinoformimine $(\mathbf{2 2})^{17}$ could be cleaved to form a diazo intermediate (similar to 25), which gave, after intramolecular cyclization, the isolated pyrazoles. In our case $\mathrm{HBr}$ could be easily eliminated from the first intermediate $(\mathbf{2 3}, \mathrm{R}=\mathrm{Br})$ leading to the stable, isolated 19.

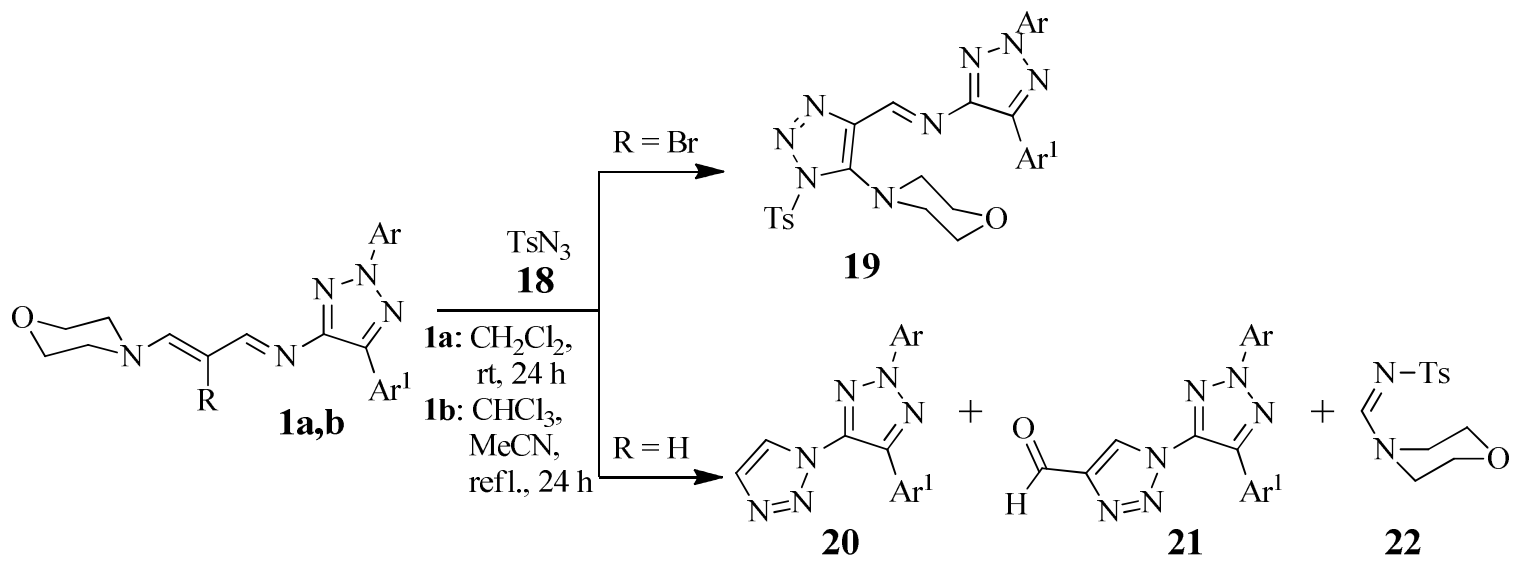

Scheme 7. Reaction of 1a,b with 4-toluenesulfonyl azide.

If no bromine substituent was present (started from 1a), a scission of the N-N bond adjacent to the tosyl group of intermediate $23(\mathrm{R}=\mathrm{H})$ took place to give $\mathbf{2 4}$ (Scheme 8). 


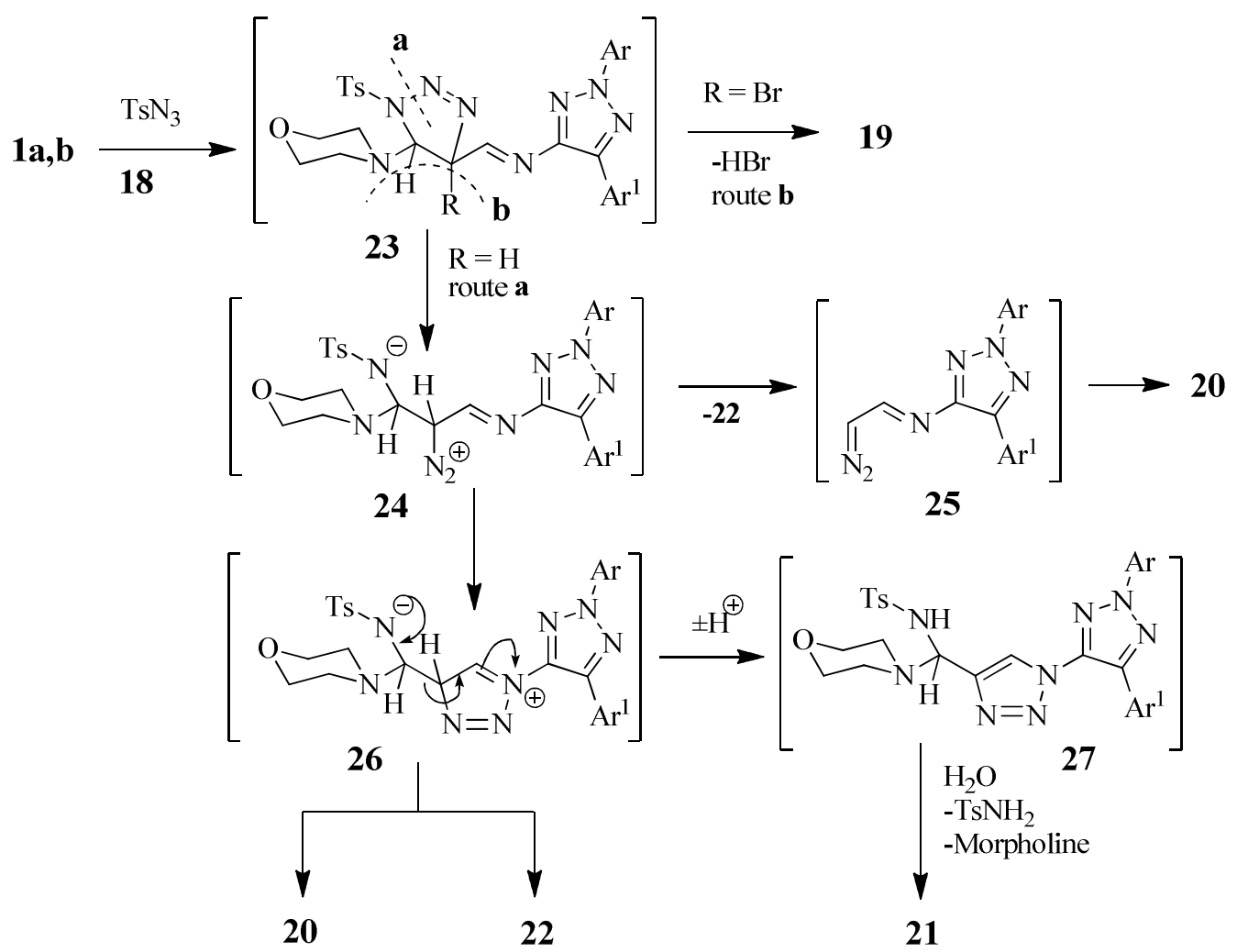

Scheme 8. Explanation of formation of products with 4-toluenesulfonyl azide.

The diazo intermediate $\mathbf{2 4}$ could react further in two different ways. According to the first, $\mathrm{N}$ (4-toluenesulfonyl)morpholinoformimine (22) was cleaved to give the triazolyltriazole derivative 20 (via intermediate 25). The other possibility for the reaction of intermediate $\mathbf{2 4}$ was the cyclization to 26. This could react further also in two possible ways: a deprotonation at the triazole ring and protonation at the tosyl group was leading to 27 . The hydrolysis of the aminal moiety furnished the other isolated product (21). The other possibility for the reaction of intermediate $\mathbf{2 6}$ was the cleavage of $\mathbf{2 2}$ to afford $\mathbf{2 0 .}$

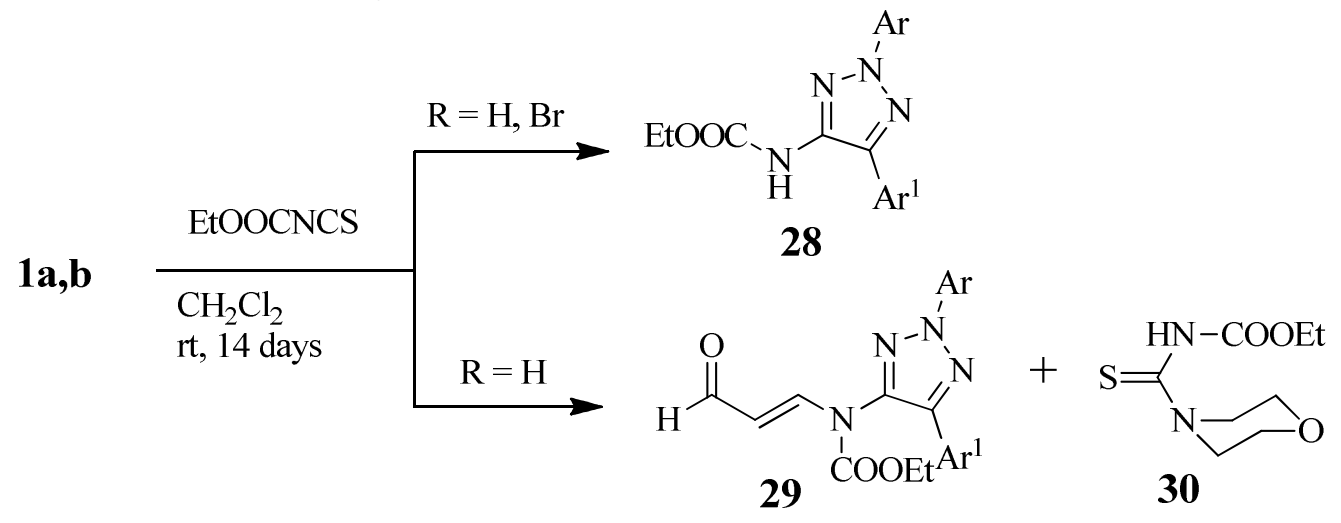

Scheme 9. Reaction of ethoxycarbonyl isothiocyanate with 1a,b. 
Isothiocyanates are widely used in $[4+2]^{18,19}$ or $[3+2]^{20}$ cycloaddition reactions. As the further reagent ethoxycarbonyl isothiocyanate was chosen in the reaction with $\mathbf{1 a , b}$.

Contrary to our expectations, this reagent proved to be only an acylating agent that formed in the first step very probably the intermediates $\mathbf{3 1}$ and $\mathbf{3 2}$ in a slow reaction at room temperature ( 2 weeks) (see Scheme 10). These intermediates were hydrolysed in two routes: the route a gave 28 while the other possible way (route b) gave 29. In the course of the reaction, morpholine was liberated, which reacted with the reagent ethoxycarbonyl isothiocyanate to give 1(ethoxycarbonyl)amino-1-morpholinomethanethione $(\mathbf{3 0})^{21}$.

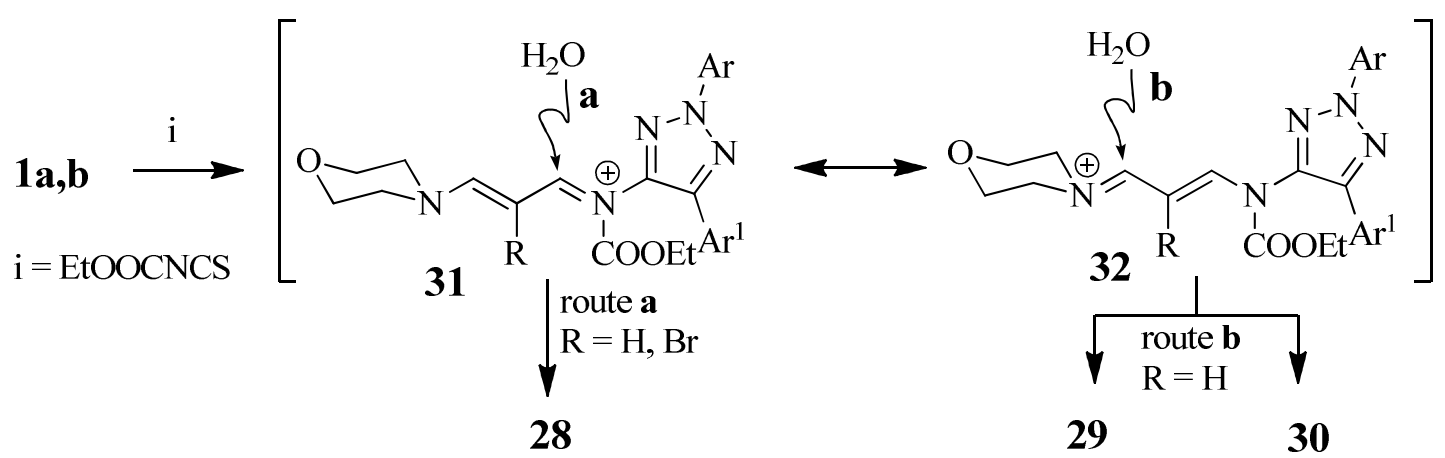

Scheme 10. Proposed intermediates leading to products 28-30.

The last dienophile used was diethyl azodicarboxylate (33). Its prolonged heating $(50 \mathrm{~h})$ with 1b in a $1: 1$ mixture of chloroform and acetonitrile gave a complex mixture from which symdiethyl hydrazinedicarboxylate $22(\mathbf{3 4}, 24 \%)$ and traces of $\mathbf{3}$ were isolated.
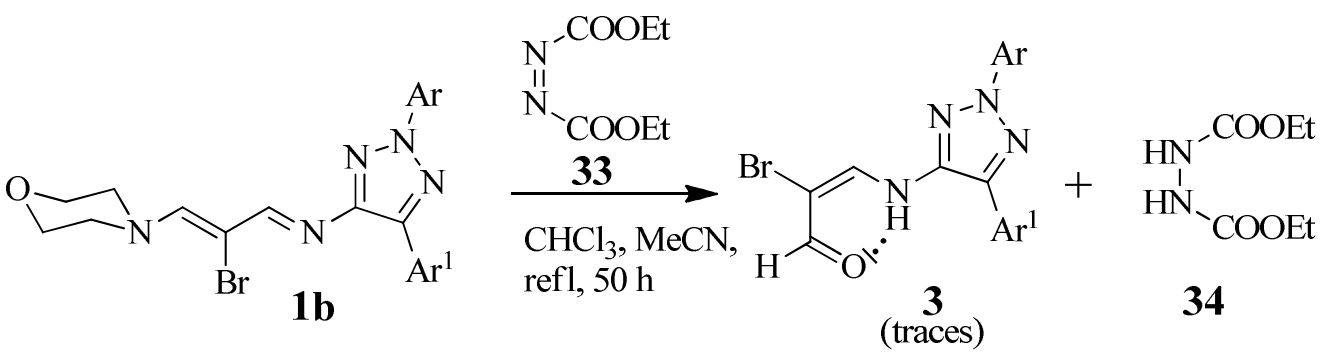

Scheme 11. Attempted reaction of diethyl azodicarbocylate with $\mathbf{1 b}$.

The reaction of 1a,b with dimethyl 1,2,4,5-tetrazinedicarboxylate (35) (a Diels-Alder reaction with inverse electron demand ${ }^{23}$ ) was also tried. When 1 a was reacted with 1 equivalent of dimethyl 1,2,4,5-tetrazine-3,6-dicarboxylate (35) in dichloroethane at room temperature, vigorous gas evolution was observed, the solution turned yellow within few minutes and crystals were separated. The structure elucidation of the product proved that the compound was the pyridazine derivative 37 . 


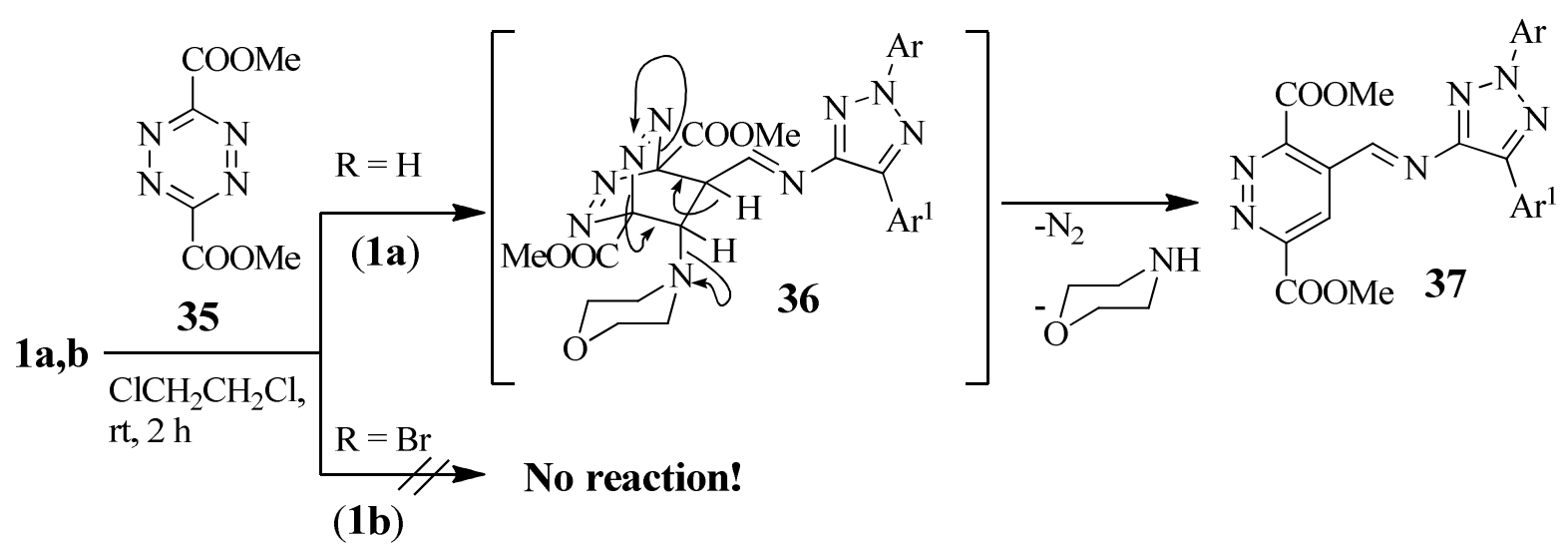

Scheme 11. Reaction of vinamidines 1a,b with dimethyl 1,2,4,5-tetrazinedicarboxylate (35).

Although the tetrazine derivative disappeared from the reaction mixture rapidly, the conversion of 1a was only $78.4 \%$ (the isolated yield of $\mathbf{3 7}$ was $70 \%$, based on the recovered 1a). The repeated reaction with 2.4 equivalents of tetrazine resulted in the isolation of $\mathbf{3 7}$ in $91 \%$ yield!

The formation of $\mathbf{3 7}$ can be explained by the first addition of the activated, electron rich double bond next to the morpholine moiety of 1a to the highly electrondeficiant aromatic ring (in positions 3 and 6) of tetrazine $\mathbf{3 5}$ forming the intermediate 36. This bicyclic intermediate aromatizes by loosing $\mathrm{N}_{2}$ and morpholine to give the isolated pyridazine derivative 37 .

The attempted reaction of $\mathbf{1 b}$ with tetrazinedicarboxylate was unsuccessful. The vinamidine 1b remained unchanged even after prolonged stirring in dichloroethane with $\mathbf{3 5}$.

\section{Conclusions}

In the present paper we described the synthesis of new representatives of a few important azaheterocyclic ring systems (e.g., pyrazoles, 1,2,3-triazoles and pyridazines). The members of these ring systems have a wide range of applications.

The biological activity of pyrazole derivatives is recognized long ago as reviewed by R. E. Orth in as early as $1968 .{ }^{24}$ Pyrazoles have been reported as potential anti-obesity agents. ${ }^{25}$ They are promising scaffolds for the synthesis of antiinflammatory and/or antimicrobial agents ${ }^{26}$ and show potential in the crop protection chemistry. ${ }^{27} \mathrm{~J} .-\mathrm{Y}$. Yoon et al. $^{28}$ recently reviewed the advances in the regioselective synthesis of pyrazole derivatives.

The different 1,2,3-triazole derivatives have also important biological activities as reviewed earlier by R. Boehm and Ch. Karow ${ }^{29}$ and recently by I. Pibiri and S. Buscemi. ${ }^{30}$ The well known method making 1,2,3-triazole derivatives, the click chemistry, has a growing impact on the drug discovery. ${ }^{31-33}$ The copper-free variations ${ }^{34,35}$ enable to perform the click reaction in living animals. 
Pyridazine derivatives (especially pyridazin-3-ones) have been considered as a magic moiety (wonder nucleus), ${ }^{36}$ which posses almost all types of biological activities, ${ }^{37}$ among others cardiovascular ${ }^{38}$ antimicrobial,${ }^{39}$ and analgesic. ${ }^{40}$

\section{Experimental Section}

General. Melting points were determined by a Büchi apparatus. IR spectra ( $\mathrm{KBr}$ pellet) were recorded on Specord IR-75 and Bruker IFS-28 equipments. The ${ }^{1} \mathrm{H}-\mathrm{NMR}$ spectra were measured on Varian XL-100 (100 MHz), Varian VXR-400 and Bruker DRX-400 instruments (400 MHz) at ambient temperature using TMS as internal standard. ${ }^{13} \mathrm{C}$ NMR spectra were recorded on a Bruker DRX-400 instrument. The yields of the reactions were not optimized.

Reaction of 2-(4-bromophenyl)-5-(4-chlorophenyl)-4-(4-morpholino-3-bromo-1-aza-1,3butadien-1-yl)-1,2,3-triazole $1 \mathbf{b}$ with morpholine. A solution of $\mathbf{1 b}(280 \mathrm{mg}, 0.5 \mathrm{mmol})$ in a mixture of $\mathrm{CH}_{2} \mathrm{Cl}_{2}(5 \mathrm{ml})$ and acetonitrile $(5 \mathrm{ml})$ was stirred with morpholine $(210 \mathrm{mg}, 0.21 \mathrm{ml}$, $2.4 \mathrm{mmol}$ ) and morpholinium perchlorate $(95 \mathrm{mg}, 0.5 \mathrm{mmol})$ at room temperature for 2 weeks. Water $(20 \mathrm{ml})$ was added, the layers were separated and the upper layer was extracted with $\mathrm{CH}_{2} \mathrm{Cl}_{2}(2 \times 10 \mathrm{ml})$. The combined organic extract was dried on $\mathrm{MgSO}_{4}$, filtered and evaporated to dryness. The residue was chromatographed on silica gel with $\mathrm{CH}_{2} \mathrm{Cl}_{2}$ to give 3 products. 4Amino-2-(4-bromophenyl)-5-(4-chlorophenyl)-1,2,3-triazole (2). Yield 1.7\%, $3 \mathrm{mg}, \mathrm{mp} \mathrm{178-}$ $180^{\circ} \mathrm{C}$ (Lit. ${ }^{1} \mathrm{mp}$ 178-180 $\left.{ }^{\circ} \mathrm{C}\right)$. 4-[(2-Bromo-2-propenal-3-yl)amino]-2-(4-bromophenyl)-5-(4chlorophenyl)-1,2,3-triazole (3). Pale yellow crystals; yield 37\%, $90 \mathrm{mg}, \mathrm{mp} 192-193^{\circ} \mathrm{C}$ (acetonitrile) (Lit. ${ }^{1} \mathrm{mp}$ 191-192 ${ }^{\circ} \mathrm{C}$ ). 2-(4-Bromophenyl)-5-(4-chlorophenyl)-4-(3-hydroxy-4morpholino-1-aza-1,3-butadien-1-yl)-1,2,3-triazole (4). Pale yellow crystals; yield 28.7\%, $70 \mathrm{mg}$, mp 226-228 ${ }^{\circ} \mathrm{C}$ (acetonitrile). ${ }^{1} \mathrm{H}$ NMR (DMSO- $d_{6}$ ): $\delta_{\mathrm{H}} 9.10$ (s, $\left.1 \mathrm{H}, \mathrm{H}-2\right), 9.02$ (br, $1 \mathrm{H}, \mathrm{OH}$ ), 7.99 (m, 2H, H-2',6'(4-Cl-phenyl)), 7.86 (m, 2H, H-2',6'(4-Br-phenyl)), 7.78 (m, 2H, H-3',5'(4-Brphenyl)), 7.70 (s, 1H, H-4), 7.65 (m, 2H, H-3',5'(4-Cl-phenyl)), 3.64 (t, 4H, H-morpholino), 2.95 (t, 4H, H-morpholino). ${ }^{1} \mathrm{H}$ NMR $\left(\mathrm{CDCl}_{3}\right): \delta_{\mathrm{H}} 9.53\left(\mathrm{~d},{ }^{3} \mathrm{~J}_{\mathrm{HH}}=4.0 \mathrm{~Hz}, \mathrm{H}-2\right)$ and $9.24(\mathrm{~s}, \mathrm{H}-2)$ ratio: 13:87, 8.24 (br, OH), 7.95 (m, 2H, H-2',6'(4-Cl-phenyl)), 7.76 (s, H-4) and 7.75 (s, H-4) ratio: $\underline{17: 83}, 7.67$ (m, 2H, H-2',6'(4-Br-phenyl)), 7.62 (m, 2H, H-3',5'(4-Br-phenyl)), 7.55 (m, 2H, H3',5'(4-Cl-phenyl)), 3.84 (t, H-morpholino) and 3.76 (t, H-morpholino) ratio: 15:85, 3.10 (m, Hmorpholino) and 2.89 (m, H-morpholino) ratio: 85:15. ${ }^{13} \mathrm{C}$ NMR (DMSO- $\left.d_{6}\right): \delta_{\mathrm{C}} 188.21,148.81$, 145.58, 138.37, 137.47, 134.15, 133.09, 130.54, 129.59, 128.94, 128.19, 120.50, 120.17, 67.32, 50.10. Anal. Calcd for $\mathrm{C}_{21} \mathrm{H}_{19} \mathrm{BrClN}_{5} \mathrm{O}_{2}$ (417.76): C, 51.60; H, 3.92; N, 14.33\%. Found: $\mathrm{C}$, $51.46 ; \mathrm{H}, 3.82 ; \mathrm{N}, 14.18 \%$.

Reaction of 2-(4-bromophenyl)-5-(4-chlorophenyl)-4-(4-morpholino-3-bromo-1-aza-1,3butadien-1-yl)-1,2,3-triazole $\mathbf{1 b}$ with $\mathbf{H C l} / \mathbf{H}_{2} \mathbf{O}$. A suspension of $\mathbf{1 b}(280 \mathrm{mg}, 0.5 \mathrm{mmol})$ in $\mathrm{CHCl}_{3}(3 \mathrm{ml})$ and ethanol $(3 \mathrm{ml})$ was refluxed with $35 \% \mathrm{HCl}(1 \mathrm{ml})$ for $1 \mathrm{~h}$. Water $(15 \mathrm{ml})$ was added, neutralized by $2 \mathrm{~N} \mathrm{NaOH}$ solution and the yellow precipitate was filtered off, washed with 
water and recrystallized from DMF to give $120 \mathrm{mg}(68.6 \%)$ of pale yellow prisms of 5 that is the salt of 2 with $\mathbf{6}, \mathrm{mp} 275-276^{\circ} \mathrm{C}$. This salt $(\mathbf{5}, 80 \mathrm{mg}, 0.11 \mathrm{mmol})$ was chromatographed on silica gel with $\mathrm{CH}_{2} \mathrm{Cl}_{2}$ to give two products: 5-aminotriazole 2, white crystals, yield $60 \%, 24 \mathrm{mg}, \mathrm{mp}$ 178-179 ${ }^{\circ} \mathrm{C}$ (Lit. ${ }^{1} \mathrm{mp} 178-180^{\circ} \mathrm{C}$ ). 2-(4-Bromophenyl)-5-(4-chlorophenyl)-1,2,3-triazole-5(1H)one 6b. Yellow solid, yield 50\%, $20 \mathrm{mg}, \mathrm{mp} 273-275^{\circ} \mathrm{C}(\mathrm{DMF})$; IR $\left(v_{\max }, \mathrm{cm}^{-1}\right)$ : 3413, 3066, 1644, $1582,1547,1488,1412,1317,1291,1263,1197,1180 .{ }^{1} \mathrm{H}$ NMR (pyridine-d $5, \mathrm{~T}=353 \mathrm{~K}$ ): $\delta_{\mathrm{H}}$ 8.80 (br, 1H, NH), 8.26 (m, 2H, H-2',6'(4-Cl-phenyl)), 8.07 (d, 2H, H-2',6'(4-Br-phenyl)), 7.72 (d, 2H, H-3',5'(4-Br-phenyl)), 7.53 (m, 2H, H-3',5'(4-Cl-phenyl)). ${ }^{13} \mathrm{C} \mathrm{NMR}\left(\mathrm{CDCl}_{3}\right)$ : $\delta_{\mathrm{C}} 168.9$, 139.6, 137.0, 135.2, 129.6, 128.9, 128.1, 127.6, 117.5, 112.6. Anal. Calcd for $\mathrm{C}_{14} \mathrm{H}_{9} \mathrm{BrClN}_{3} \mathrm{O}$ (348.96): C, 47.96; H, 2.59; N, 11.99\%. Found: C, 47.82; H, 2.71; N, $12.04 \%$.

Reaction of 2-(4-bromophenyl)-5-(4-chlorophenyl)-4-(4-morpholino-3-bromo-1-aza-1,3butadien-1-yl)-1,2,3-triazole $1 \mathrm{~b}$ with 4-bromophenylhydrazine hydrochloride. A solution of the azadiene $(\mathbf{1 b}, 280 \mathrm{mg}, 0.5 \mathrm{mmol})$ in a mixture of ethanol $(5 \mathrm{ml})$ and $\mathrm{CHCl}_{3}(5 \mathrm{ml})$ was refluxed with 4-bromophenylhydrazine hydrochloride $(120 \mathrm{mg}, 0.5 \mathrm{mmol})$ for $30 \mathrm{~min}$. The reaction mixture was cooled, the precipitated crystals were filtered off and recrystallized from ethanol to give white needles of 2 (120 mg, 67.6\%), mp 179-180 ${ }^{\circ} \mathrm{C}$ (Lit. ${ }^{1} \mathrm{mp} 178-180{ }^{\circ} \mathrm{C}$ ). The evaporation of the mother liquor of the first filtration to dryness and chromatography of the residue on silica gel with $\mathrm{CH}_{2} \mathrm{Cl}_{2}$ resulted in white needles of 4-bromo-1-(4bromophenyl)pyrazole (7). Yield $81.3 \%, 125 \mathrm{mg}, \mathrm{mp} 83-85^{\circ} \mathrm{C}$ (petroleum ether) (Lit. ${ }^{5} \mathrm{mp} 84.5$ $\left.85{ }^{\circ} \mathrm{C}\right) .{ }^{1} \mathrm{H}$ NMR $\left(\mathrm{CDCl}_{3}\right): \delta_{\mathrm{H}} 7.92$ (s, 1H, H-3), 7.68 (s, 1H, H-5), 7.59 (m, 2H, H-2',6'(4-Brphenyl)), 7.54 (m, 2H, H-3',5'(4-Br-phenyl)). Anal. Calcd for $\mathrm{C}_{9} \mathrm{H}_{6} \mathrm{Br}_{2} \mathrm{~N}_{2}$ (301.99): C, 35.79; $\mathrm{H}$, $2.00 ;$ N, 9.28\%. Found: C, 35.56; H, 1.97; N, 9.04\%.

Reaction of 1a with 4-nitrobenzenediazonium fluoroborate: formation of 3-[2-(4bromophenyl)-5-(4-chlorophenyl)-2H-1,2,3-triazol-4-ylimino]-2-[(4-nitrophenyl)hydrazo-

no]propionaldehyde (9). A solution of 4-nitrobenzenediazonium fluoroborate (80 $\mathrm{mg}, 0.33$ mmol) in acetonitrile $(5 \mathrm{ml})$ was added to a stirred solution of $\mathbf{1 a}(150 \mathrm{mg}, 0.31 \mathrm{mmol})$ in $\mathrm{CH}_{2} \mathrm{Cl}_{2}$ $(5 \mathrm{ml})$ at room temperature. An orange solid was separated within $1 \mathrm{~min}$. The suspension was stirred for $20 \mathrm{~min}$ and it was mixed with diethyl ether $(15 \mathrm{ml})$ and filtered off, washed with diethyl ether. The crude product was suspended in water $(10 \mathrm{ml})$, mixed with $20 \%$ aq. $\mathrm{NaOH}$ solution $(2 \mathrm{ml})$ and extracted with $\mathrm{CH}_{2} \mathrm{Cl}_{2}(4 \times 5 \mathrm{ml})$. The organic extract was concentrated and chromatographed on silica gel with toluene to give an orange solid. Yield 83\%, $150 \mathrm{mg}, \mathrm{mp} 268$ $270^{\circ} \mathrm{C} .{ }^{1} \mathrm{H}$ NMR $\left(\mathrm{CDCl}_{3}\right): \delta_{\mathrm{H}} 15.22(\mathrm{br}, 1 \mathrm{H}, \mathrm{NH}), 9.70$ (s, 1H, H-1), 9.45 (s, 1H, H-3), 8.31 (d, 2H, H-3,5(4-NO $\mathrm{N}_{2}$-phenyl)), 8.07 (d, 2H, H-2,6(4- $\mathrm{NO}_{2}$-phenyl)), 7.93 (d, 2H, H-2,6(4-Cl-phenyl)), 7.67 (d, 2H, H-2,6(4-Br-phenyl)), 7.54 (d, 2H, H-3,5(4-Br-phenyl)), 7.39 (d, 2H, H-3,5(4-Clphenyl)). ${ }^{13} \mathrm{C} \mathrm{NMR}\left(\mathrm{CDCl}_{3}\right): \delta_{\mathrm{C}} 164.1,162.7,158.2,146.5,142.9,142.2,136.7,131.0,129.7$, 129.0, 124.5, 123.7, 122.1, 116.6, 113.4. Anal. Calcd for $\mathrm{C}_{23} \mathrm{H}_{15} \mathrm{BrClN}_{7} \mathrm{O}_{3}$ (552.80): C, 49.98; $\mathrm{H}$, 2.74; N, 17.74\%. Found: C, 49.84; H, 2.78; N, 17.48\%.

Reaction of $\mathbf{1 b}$ with 4-nitrobenzenediazonium fluoroborate. The reaction of $\mathbf{1 b}$ (170 $\mathrm{mg}, 0.31$ $\mathrm{mmol}$ ) with 4-nitrobenzenediazonium fluoroborate $(80 \mathrm{mg}, 0.33 \mathrm{mmol})$ under the same reaction conditions and work up gave two compounds: 4-amino-2-(4-bromophenyl)-5-(4-chlorophenyl)- 
1,2,3-triazole (2). White crystals, yield $36.7 \%, 40 \mathrm{mg}, \mathrm{mp} 178-180^{\circ} \mathrm{C}$ (Lit. $\left.{ }^{1} \mathrm{mp} 178-180^{\circ} \mathrm{C}\right) .3-[2$ (4-Bromophenyl)-5-(4-chlorophenyl)-2H-1,2,3-triazol-4-ylimino]-2-[(4-nitrophenyl)hydrazono]propionaldehyde (9). Orange crystals, yield 31.7\%, $57 \mathrm{mg}, \mathrm{mp} 269-271^{\circ} \mathrm{C}$. The compound was identical with that described above.

Reaction of 2-(4-bromophenyl)-5-(4-chlorophenyl)-4-(4-morpholino-1-aza-1,3-butadien-1yl)-1,2,3-triazole 1a with tetrabutylammonium borohydride. A solution of $1 \mathrm{a}$ (235 $\mathrm{mg}, 0.5$ $\mathrm{mmol})$ in $\mathrm{CH}_{2} \mathrm{Cl}_{2}(3 \mathrm{ml})$ and ethanol $(3 \mathrm{ml})$ was stirred with tetrabutylammonium borohydride $(270 \mathrm{mg}, 1.05 \mathrm{mmol})$ at room temperature for $24 \mathrm{~h}$. Water $(10 \mathrm{ml})$ was added and extracted with $\mathrm{CH}_{2} \mathrm{Cl}_{2}(3 \times 5 \mathrm{ml})$. The organic extract was dried on $\mathrm{MgSO}_{4}$, filtered and evaporated, the residue was chromatographed on silica gel with $\mathrm{CH}_{2} \mathrm{Cl}_{2}$ to give two different products $(26 \mathrm{mg}, 11 \%$ of starting material 1a was also recovered). 2-(4-Bromophenyl)-5-(4-chlorophenyl)-4-(3morpholinoprop-1-ylamino)-1,2,3-triazole (10). White crystals, yield 50.9\%, $108 \mathrm{mg}$, mp 125$126^{\circ} \mathrm{C}$ (ethanol-water). ${ }^{1} \mathrm{H}$ NMR $\left(\mathrm{CDCl}_{3}\right): \delta_{\mathrm{H}} 7.79\left(\mathrm{~m}, 2 \mathrm{H}, \mathrm{H}-2^{\prime}, 6^{\prime}(4-\mathrm{Cl}-\right.$ phenyl)), $7.66(\mathrm{~m}, 2 \mathrm{H}, \mathrm{H}-$ 2',6'(4-Br-phenyl)), 7.46 (m, 2H, H-3',5'(4-Br-phenyl)), 7.37 (m, 2H, H-3',5'(4-Cl-phenyl)), 5.08 (m, 1H, NH), 3.55 (m, 4H, H-morpholino), 3.42 (m, 2H, H-3), 2.46 (m, 2H, H-1), 2.39 (m, 4H, H-morpholino), 1.18 (d, 2H, H-2). ${ }^{13} \mathrm{C} \mathrm{NMR}\left(\mathrm{CDCl}_{3}\right): \delta_{\mathrm{C}} 151.54,138.83,133.95,133.82,132.09$, 129.23, 128.85, 127.81, 127.69, 119.13, 118.85, 65.04, 57.01, 53.02, 43.14, 23.73. Anal. Calcd for $\mathrm{C}_{21} \mathrm{H}_{23} \mathrm{BrClN}_{5} \mathrm{O}$ (476.83): C, 52.90; H, 4.86; N, 14.69\%. Found: C, 53.16; H, 4.88; $\mathrm{N}$, 14.80\%. 2-(4-Bromophenyl)-5-(4-chlorophenyl)-4-(prop-1-ylamino)-1,2,3-triazole (12a). White crystals, yield $5.7 \% 10 \mathrm{mg}, \mathrm{mp} 175-177^{\circ} \mathrm{C} .{ }^{1} \mathrm{H}$ NMR $\left(\mathrm{CDCl}_{3}\right): \delta_{\mathrm{H}} 7.87\left(\mathrm{~m}, 2 \mathrm{H}, \mathrm{H}-2^{\prime}, 6{ }^{\prime}(4-\mathrm{Cl}-\right.$ phenyl)), 7.69 (m, 2H, H-2',6'(4-Br-phenyl)), 7.55 (m, 2H, H-3',5'(4-Br-phenyl)), 7.45 (m, 2H, H$\left.3^{\prime}, 5^{\prime}(4-C l-p h e n y l)\right), 4.82(\mathrm{br}, 1 \mathrm{H}, \mathrm{NH}), 3.36\left(\mathrm{t},{ }^{3} J_{\mathrm{HH}}=1 \mathrm{~Hz}, 2 \mathrm{H}, \mathrm{N}-\mathrm{CH}_{2}\right), 1.74\left(\right.$ hept,${ }^{3} J_{\mathrm{HH}}=7.2 \mathrm{~Hz}$, $\left.2 \mathrm{H}, \mathrm{CH}_{2}\right), 1.03\left(\mathrm{t},{ }^{3} J_{\mathrm{HH}}=7.4 \mathrm{~Hz}, 3 \mathrm{H}, \mathrm{CH}_{3}\right) .{ }^{13} \mathrm{C} \mathrm{NMR}\left(\mathrm{CDCl}_{3}\right): \delta_{\mathrm{C}} 162.1,142.4,138.9,131.2$, 127.7, 127.5, 126.6, 120.6, 118.8, 48.0, 22.5, 11.5. Anal. Calcd for $\mathrm{C}_{17} \mathrm{H}_{16} \mathrm{BrClN}_{4}$ (391.72): C, 52.13 ; H, 4.12; N, 14.30\%. Found: C, 52.28; H, 4.19; N, 14.18\%.

Reaction of 2-(4-bromophenyl)-5-(4-chlorophenyl)-4-(4-morpholino-3-bromo-1-aza-1,3butadien-1-yl)-1,2,3-triazole $1 \mathrm{~b}$ with tetrabutylammonium borohydride. A solution of $1 \mathrm{~b}$ (550 mg, $1.0 \mathrm{mmol})$ in $\mathrm{CH}_{2} \mathrm{Cl}_{2}(3 \mathrm{ml})$ and ethanol $(3 \mathrm{ml})$ was stirred with tetrabutylammonium borohydride $(760 \mathrm{mg}, 3 \mathrm{mmol})$ at room temperature for $24 \mathrm{~h}$. Water $(40 \mathrm{ml})$ was added and the mixture was extracted with $\mathrm{CH}_{2} \mathrm{Cl}_{2}(3 \times 10 \mathrm{ml})$. The organic extract was dried on $\mathrm{MgSO}_{4}$, filtered and evaporated, the residue was chromatographed on silica gel with $\mathrm{CH}_{2} \mathrm{Cl}_{2}$-methanol = 9:1 to give 4 different products. 4-[(2-Bromopropene-3-one-1-yl)amino]-2-(4-bromophenyl)-5(4-chlorophenyl)-1,2,3-triazole (3). White crystals, yield $2.3 \%, 13 \mathrm{mg}, \mathrm{mp} 189-191^{\circ} \mathrm{C}$ (acetonitrile) (Lit. ${ }^{1} \mathrm{mp}$ 191-192 $\left.{ }^{\circ} \mathrm{C}\right)$. 2-(4-Bromophenyl)-5-(4-chlorophenyl)-4-(3-morpholinoprop-1-ylamino)-1,2,3-triazole (10). White crystals, yield $21.0 \%, 100 \mathrm{mg}, \mathrm{mp} 125-126^{\circ} \mathrm{C}$. The compound was identical with that described above. 2-(4-Bromophenyl)-5-(4-chlorophenyl)-4-(2morpholinoprop-1-ylamino)-1,2,3-triazole (11). White crystals, yield 31.5\%, $150 \mathrm{mg}$, mp 112$114^{\circ} \mathrm{C}$ (ethanol-water). ${ }^{1} \mathrm{H}$ NMR $\left(\mathrm{CDCl}_{3}\right): \delta_{\mathrm{H}} 7.88\left(\mathrm{~m}, 2 \mathrm{H}, \mathrm{H}-2^{\prime}, 6^{\prime}(4-\mathrm{Cl}-\right.$ phenyl)), $7.75(\mathrm{~m}, 2 \mathrm{H}, \mathrm{H}-$ 2',6'(4-Br-phenyl)), 7.54 (m, 2H, H-3',5'(4-Br-phenyl)), 7.46 (m, 2H, H-3',5'(4-Cl-phenyl)), 5.08 (d, $\left.{ }^{3} J_{\mathrm{HH}}=7.3 \mathrm{~Hz}, 1 \mathrm{H}, \mathrm{NH}\right), 3.67$ (m, 4H, H-morpholino), 3.43 (m, 1H, H-1a), 3.17 (t, 1H, H-1b), 
2.96 (m, 1H, H-2), 2.64 (m, 2H, H-morpholino), 2.47 (m, 2H, H-morpholino), 1.09 (d, ${ }^{3} \mathrm{~J}_{\mathrm{HH}}=6.6$ $\left.\mathrm{Hz}, 3 \mathrm{H}, \mathrm{CH}_{3}\right) .{ }^{13} \mathrm{C}$ NMR $\left(\mathrm{CDCl}_{3}\right): \delta_{\mathrm{C}} 151.6,138.6,133.6,133.5,131.8,128.9,127.3,118.6$, 67.2, 57.9, 47.9, 46.3, 11.0. Anal. Calcd for $\mathrm{C}_{21} \mathrm{H}_{23} \mathrm{BrClN}_{5} \mathrm{O}$ (476.83): C, 52.90; H, 4.86; N, 14.69\%. Found: C, 53.00; H, 4.76; N, 14.87\%. 2-(4-Bromophenyl)-4-(2-bromoprop-1-ylamino)5-(4-chloro-phenyl)-1,2,3-triazole (12b). White crystals, yield $6.8 \%, 32 \mathrm{mg}, \mathrm{mp} 108-110^{\circ} \mathrm{C}$ (ethanol-water). ${ }^{1} \mathrm{H}$ NMR $\left(\mathrm{CDCl}_{3}\right): \delta_{\mathrm{H}} 7.86\left(\mathrm{~m}, 2 \mathrm{H}, \mathrm{H}-2^{\prime}, 6^{\prime}\left(4-\mathrm{Cl}\right.\right.$-phenyl)), $7.71\left(\mathrm{~m}, 2 \mathrm{H}, \mathrm{H}-2^{\prime}, 66^{\prime}(4-\right.$ Br-phenyl)), 7.56 (m, 2H, H-3',5'(4-Br-phenyl)), 7.47 (m, 2H, H-3',5'(4-Cl-phenyl)), 4.55 (m, 1H, $\mathrm{H}-2), 4.40$ (t, 1H, NH), 3.81 (m, 1H, H-1a), 3.55 (m, $1 \mathrm{H}, \mathrm{H}-1 \mathrm{~b}), 1.82\left(\mathrm{~d},{ }^{3} J_{\mathrm{HH}}=6.7 \mathrm{~Hz}, 3 \mathrm{H}, \mathrm{CH}_{3}\right)$. ${ }^{13} \mathrm{C}$ NMR $\left(\mathrm{CDCl}_{3}\right): \delta_{\mathrm{C}} 150.5,138.5,133.9,133.8,131.9,129.1,128.5,127.5,118.9,118.7,52.6$, 50.0, 23.3. Anal. Calcd for $\mathrm{C}_{17} \mathrm{H}_{15} \mathrm{Br}_{2} \mathrm{ClN}_{4}$ (470.63): C, 43.39; H, 3.21; N, 11.91\%. Found: $\mathrm{C}$, $43.60 ; \mathrm{H}, 3.37 ; \mathrm{N}, 11.89 \%$.

Dimethyl 2-\{[2-(4-bromophenyl)-5-(4-chlorophenyl)-2H-1,2,3-triazol-4-yl](3-oxopropenyl)amino\}but-2-enedioate (15). A solution of $1 \mathbf{a}(120 \mathrm{mg}, 0.25 \mathrm{mmol})$ in dichloroethane $(3 \mathrm{ml})$ was stirred with dimethyl acetylenedicarboxylate $(140 \mathrm{mg}, 0.12 \mathrm{ml}, 1 \mathrm{mmol})$ at room temperature for $7 \mathrm{~h}$. The reaction mixture was chromatographed on silica gel with a mixture of hexane : ethyl acetate $=8: 2$ to give white crystals. Yield $37 \%, 52 \mathrm{mg}, \mathrm{mp} 143-145^{\circ} \mathrm{C} ;{ }^{1} \mathrm{H}$ NMR $\left(\mathrm{CDCl}_{3}\right): \delta_{\mathrm{H}} 9.37$ $\left(\mathrm{d},{ }^{3} J_{\mathrm{HH}}=7.6 \mathrm{~Hz}, 1 \mathrm{H}, \mathrm{CHO}\right), 8.00\left(\mathrm{~m}, 2 \mathrm{H}, \mathrm{H}-2^{\prime}, 6^{\prime}(4-\mathrm{Cl}-\right.$ phenyl)), 7.73 (m, 2H, H-2',6'(4-Brphenyl)), 7.68 (m, 2H, H-3',5'(4-Br-phenyl)), 7.45 (m, 2H, H-3',5'(4-Cl-phenyl)), 7.37 (d, 1H, ${ }^{3} J_{\mathrm{HH}}=13.4 \mathrm{~Hz}, \mathrm{H}-1$ (propenyl)), $5.26\left(\mathrm{dd},{ }^{3} J_{\mathrm{HH}}=13.4,7.6 \mathrm{~Hz}, 1 \mathrm{H}, \mathrm{H}-2\right.$ (propenyl)), 5.25 (s, $1 \mathrm{H}$, $\mathrm{H}-3), 4.02\left(\mathrm{~s}, 3 \mathrm{H}, \mathrm{OCH}_{3}\right), 3.68\left(\mathrm{~s}, 3 \mathrm{H}, \mathrm{OCH}_{3}\right) .{ }^{13} \mathrm{C} \mathrm{NMR}\left(\mathrm{CDCl}_{3}\right): \delta_{\mathrm{C}} 189.67,165.23,163.37$, $148.91,147.42,142.42,139.16,137.90,136.22,132.69,129.56,127.79,125.55,122.58,120.29$, 113.99, 102.81, 53.95, 52.02. Anal. Calcd. for $\mathrm{C}_{23} \mathrm{H}_{18} \mathrm{BrClN}_{4} \mathrm{O}_{5}$ x $0.6 \mathrm{H}_{2} \mathrm{O}$ (556.61): C, 49.63; $\mathrm{H}$, 3.48 ; N, 10.06\%. Found: C, 49.83; H, 3.54; N, 9.76\%.

Reaction of 2-(4-bromophenyl)-5-(4-chlorophenyl)-4-(4-morpholino-1-aza-1,3-butadien-1yl)-1,2,3-triazole 1a with 4-toluenesolfonyl azide (18). A solution of $1 \mathbf{a}(235 \mathrm{mg}, 0.5 \mathrm{mmol})$ in $\mathrm{CH}_{2} \mathrm{Cl}_{2}(5 \mathrm{ml})$ was stirred with 4-toluenesulfonyl azide $(18,300 \mathrm{mg}, 1.5 \mathrm{mmol})$ at room temperature for $24 \mathrm{~h}$ and the reaction mixture was chromatographed on silica gel with $\mathrm{CH}_{2} \mathrm{Cl}_{2}$ to give different products. 4-Toluenesulfonylazide (18). Yield 66.6\%, $200 \mathrm{mg}$ : recovered starting material. $N$-(4-Toluenesulfonyl)morpholinoformimine (22). Yield $24.6 \%, 33 \mathrm{mg}, \mathrm{mp} 175-177^{\circ} \mathrm{C}$ (Lit. $\left.{ }^{17} \mathrm{mp} .174-176^{\circ} \mathrm{C}\right) ;{ }^{1} \mathrm{H}$ NMR $\left(\mathrm{CDCl}_{3}\right): \delta_{\mathrm{H}} 8.20$ (s, $1 \mathrm{H}, \mathrm{H}$-formyl), 7.79 (m, 2H, H-2',6'(4toluenesulfonyl)), 7.28 (m, 2H, H-3',5'(4-toluenesulfonyl)), 3.76 (m, 2H, H-morpholino), 3.69 (m, 4H, H-morpholino), 3.50 (m, 2H, H-morpholino), 2.42 (s, 3H, $\left.\mathrm{CH}_{3}\right) \cdot{ }^{13} \mathrm{C}$ NMR $\left(\mathrm{CDCl}_{3}\right): \delta_{\mathrm{C}}$ 157.53, 142.68, 129.36, 126.58, 125.88, 66.80, 65.92, 50.30, 44.20, 21.48. Anal. Calcd for $\mathrm{C}_{12} \mathrm{H}_{16} \mathrm{~N}_{2} \mathrm{O}_{2} \mathrm{~S}$ (252.34): C, 53.71; H, 6.01; N, 10.44\%. Found: C, 53.54; H, 5.99; N, 10.45\%. $2-$ (4-Bromophenyl)-5-(4-chlorophenyl)-4-(1,2,3-triazol-1-yl)-1,2,3-triazole (20). White needles, yield $38.5 \%, 77 \mathrm{mg}, \mathrm{mp} 154-156^{\circ} \mathrm{C} .{ }^{1} \mathrm{H}$ NMR $\left(\mathrm{CDCl}_{3}\right)$ : $\delta_{\mathrm{H}} 8.06\left(\mathrm{~d},{ }^{3} J_{\mathrm{HH}}=1.1 \mathrm{~Hz}, 1 \mathrm{H}, \mathrm{H}-4^{\prime}\right), 8.04$ (m, 2H, H-2',6'(4-Cl-phenyl)), 7.94 (d, $\left.{ }^{3} J_{\mathrm{HH}}=1.1 \mathrm{~Hz}, 1 \mathrm{H}, \mathrm{H}-5^{\prime}\right), 7.67$ (m, 2H, H-2',6'(4-Brphenyl)), 7.62 (m, 2H, H-3',5'(4-Br-phenyl)), 7.40 (m, 2H, H-3',5'(4-Cl-phenyl)). ${ }^{13} \mathrm{C}$ NMR $\left(\mathrm{CDCl}_{3}\right): \delta_{\mathrm{C}} 141.36,137.98,135.98,134.18,132.67,129.27,129.17,129.13,126.01,125.32$, 122.38, 120.32. Anal. Calcd for $\mathrm{C}_{16} \mathrm{H}_{10} \mathrm{BrClN}_{6}$ (401.68): C, 47.84; H, 2.51; N, 20.92\%. Found: 
C, 47.90; H, 2.56; N, 20.75\%. 2-(4-Bromophenyl)-5-(4-chlorophenyl)-4-(4-formyl-1,2,3-triazol1-yl)-1,2,3-triazole (21). White needles, yield 38.5\%, $32 \mathrm{mg}, \mathrm{mp} 174-176{ }^{\circ} \mathrm{C} .{ }^{1} \mathrm{H} \mathrm{NMR}\left(\mathrm{CDCl}_{3}\right)$ : $\delta_{\mathrm{H}} 10.28$ (s, 1H, H-formyl), 8.59 (s, 1H, H-5"), 8.04 (m, 2H, H-2',6'(4-Cl-phenyl)), 7.70 (m, 2H, H-2',6'(4-Br-phenyl)), 7.65 (m, 2H, H-3',5'(4-Br-phenyl)), 7.44 (m, 2H, H-3',5'(4-Cl-phenyl)). ${ }^{13} \mathrm{C}$ NMR $\left(\mathrm{CDCl}_{3}\right): \delta_{\mathrm{C}} 184.34,147.66,141.50,139.53,137.80,136.37,132.78,129.29,126.74$, 125.57, 122.79, 120.38. Anal. Calcd for $\mathrm{C}_{17} \mathrm{H}_{10} \mathrm{BrClN}_{6} \mathrm{O}$ (429.69): C, 47.84; H, 2.51; N, $20.92 \%$. Found: C, 47.90; H, 2.56; N, 20.75\%. 4-Toluenesulfonamide; yield 36.8\%, $32 \mathrm{mg}$, mp 133$135^{\circ} \mathrm{C}$ (Lit. $\left.^{41} \mathrm{mp} 137^{\circ} \mathrm{C}\right)$.

Reaction of 2-(4-bromophenyl)-4-(3-bromo-4-morpholino-1-aza-1,3-butadien-1-yl)-5-(4chlorophenyl)-1,2,3-triazole $1 \mathrm{~b}$ with 4-toluenesulfonyl azide (18). A solution of $\mathbf{1 b}$ (280 mg, $0.5 \mathrm{mmol})$ in a mixture of $\mathrm{CHCl}_{3}(5 \mathrm{ml})$ and acetonitrile $(5 \mathrm{ml})$ was refluxed with 4toluenesulfonyl azide $(\mathbf{1 8}, 300 \mathrm{mg}, 1.5 \mathrm{mmol})$ for $24 \mathrm{~h}$. The reaction mixture was evaporated to dryness, the residue was chromatographed on silica gel with $\mathrm{CH}_{2} \mathrm{Cl}_{2}$ to give two products. 4-[(2Bromopropene-3-one-1-yl)amino]-2-(4-bromophenyl)-5-(4-chlorophenyl)-1,2,3-triazole (3). Pale

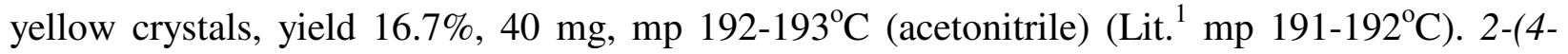
Bromophenyl)-5-(4-chlorophenyl)-4-[5-morpholino-1-(4-toluenesulfonyl)-1,2,3-triazol-4-methylidene]amino-1,2,3-triazole (19). White needles, yield 15\%, $50 \mathrm{mg}, \mathrm{mp} 245-247^{\circ} \mathrm{C} .{ }^{1} \mathrm{H}$ NMR $\left(\mathrm{CDCl}_{3}\right): \delta_{\mathrm{H}} 8.79$ (s, 1H, H-formylimino), 8.06 (m, 2H, H-2',6'(4-Cl-phenyl)), 7.70 (m, 6H, H2',3',5',6'(4-Br-phenyl) and 2',6'(4-toluenesulfonyl)), 7.43 (m, 2H, H-3',5'(4-Cl-phenyl)), 7.23 (m, 2H, H-3',5'(4-toluenesulfonyl)), 3.9 (m, 2H, H-morpholino)), 3.79 (m, 4H, H-morpholino)), 3.55 (m, 2H, H-morpholino)), $2.40\left(\mathrm{~s}, 3 \mathrm{H}, \mathrm{CH}_{3}\right) .{ }^{13} \mathrm{C} \mathrm{NMR}\left(\mathrm{CDCl}_{3}\right): \delta_{\mathrm{C}} 154.4,142.2,141.5,139.9$, 139.2, 137.6, 137.4, 135.9, 132.5, 129.4, 129.1, 128.9, 126.1, 125.2, 122.4, 120.2, 66.5, 65.9, 48.6, 45.5, 21.2. Anal. Calcd for $\mathrm{C}_{28} \mathrm{H}_{24} \mathrm{BrClN}_{8} \mathrm{O}_{3} \mathrm{~S}$ (668.00): C, 50.34; H, 3.62; N, 16.78\%. Found: C, 50.15; H, 3.56; N, 16.69\%.

Reaction of 2-(4-bromophenyl)-5-(4-chlorophenyl)-4-(4-morpholino-1-aza-1,3-butadien-1yl)-1,2,3-triazole 1a with ethoxycarbonyl isothiocyanate. A solution of 1 a (240 $\mathrm{mg}, 0.5 \mathrm{mmol})$ in $\mathrm{CH}_{2} \mathrm{Cl}_{2}(5 \mathrm{ml})$ was stirred with ethoxycarbonyl isothiocyanate $(130 \mathrm{mg}, 120 \mu \mathrm{L}, 1 \mathrm{mmol})$ at room temperature for 2 weeks. The solvent was evaporated, the residue was chromatographed on silica gel with $\mathrm{CH}_{2} \mathrm{Cl}_{2}$ to give 3 different products. 2-(4-Bromophenyl)-5-(4-chlorophenyl)-4(ethoxycarbonylamino)-1,2,3-triazole (28). Pale yellow crystals, yield 10.0\%, $42 \mathrm{mg}$, mp 195$197^{\circ} \mathrm{C}$ (diethyl ether). ${ }^{1} \mathrm{H}$ NMR $\left(\mathrm{CDCl}_{3}\right)$ : $\delta_{\mathrm{H}} 7.99$ (m, 2H, H-2',6'(4-Cl-phenyl)), 7.37 (s, 1H, NH), 7.67 (m, 2H, H-2',6'(4-Br-phenyl)), 7.52 (m, 2H, H-3',5'(4-Br-phenyl)), 7.41 (m, 2H, H-3',5'(4-Clphenyl)), $4.21\left(\mathrm{q},{ }^{3} J_{\mathrm{HH}}=7.1 \mathrm{~Hz}, 2 \mathrm{H}, \mathrm{CH}_{2}\right), 1.26\left(\mathrm{t},{ }^{3} \mathrm{~J}_{\mathrm{HH}}=7.1 \mathrm{~Hz}, 3 \mathrm{H}, \mathrm{CH}_{3}\right) .{ }^{13} \mathrm{C} \mathrm{NMR}\left(\mathrm{CDCl}_{3}\right)$ : $\delta_{\mathrm{C}} 154.0,141.4,140.7,138.5,135.0,132.5,129.1,128.3,128.0,121.2,120.0,62.5,14.4$. Anal. Calcd for $\mathrm{C}_{17} \mathrm{H}_{14} \mathrm{BrClN}_{4} \mathrm{O}_{2}$ (421.70): C, 48.41; H, 3.35; N, 13.29\%. Found: C, 48.60; H, 3.17; N, 13.49\%. 2-(4-Bromophenyl)-5-(4-chlorophenyl)-4-[N-ethoxycarbonyl(2-propene-3-one-1-yl)amino]-1,2,3-triazole monohydrate (29). Pale yellow crystals, yield 32.9\%, $81 \mathrm{mg}$, mp 168$170^{\circ} \mathrm{C} .{ }^{1} \mathrm{H} \mathrm{NMR}\left(\mathrm{CDCl}_{3}\right): \delta_{\mathrm{H}} 9.52\left(\mathrm{~d},{ }^{3} \mathrm{~J}_{\mathrm{HH}}=7.8 \mathrm{~Hz}, 1 \mathrm{H}, \mathrm{H}-1\right), 8.26\left(\mathrm{~d},{ }^{3} J_{\mathrm{HH}}=14.2 \mathrm{~Hz}, 1 \mathrm{H}, \mathrm{H}-3\right)$, 7.99 (m, 2H, H-2',6'(4-Cl-phenyl)), 7.66 (m, 2H, H-2',6'(4-Br-phenyl)), 7.60 (m, 2H, H-3',5'(4-Brphenyl)), 7.43 (m, 2H, H-3',5'(4-Cl-phenyl)), 5.38 (dd, $J_{1,2}=7.8, J_{2,3}=14.3 \mathrm{~Hz}, 1 \mathrm{H}, \mathrm{H}-2$ ), 4.25 
$\left(\mathrm{q},{ }^{3} J_{\mathrm{HH}}=6.9 \mathrm{~Hz}, 2 \mathrm{H}, \mathrm{CH}_{2}\right), 1.11\left(\mathrm{t},{ }^{3} J_{\mathrm{HH}}=6.3 \mathrm{~Hz}, 3 \mathrm{H}, \mathrm{CH}_{3}\right) \cdot{ }^{13} \mathrm{C} \mathrm{NMR}\left(\mathrm{CDCl}_{3}\right): \delta_{\mathrm{C}} 190.85$, $151.80,148.92,143.07,139.12,138.14,135.81,132.59,129.46,127.63,126.52,122.17,120.25$, 120.06, 114.34, 64.73, 14.03. Anal. Calcd for $\mathrm{C}_{20} \mathrm{H}_{16} \mathrm{BrClN}_{4} \mathrm{O}_{3} \times \mathrm{H}_{2} \mathrm{O}$ (493.77): C, 48.65; $\mathrm{H}$, 3.67 ; N, 11.35\%. Found: C, 48.89; H, 3.47; N, 11.50\%. 1-(Ethoxycarbonyl)amino-1-morpholinomethanethione (30). ${ }^{21}$ White crystals, yield $8.3 \%, 9 \mathrm{mg}, \mathrm{mp} 125-127^{\circ} \mathrm{C} ;{ }^{1} \mathrm{H} \mathrm{NMR}\left(\mathrm{CDCl}_{3}\right): \delta_{\mathrm{H}}$ $4.18\left(\mathrm{q},{ }^{3} J_{\mathrm{HH}}=7.1 \mathrm{~Hz}, 2 \mathrm{H}, \mathrm{CH}_{2}\right.$ ), 3.95 (m, 2H, H-morpholino), 3.80 (m, 4H, H-morpholino), 3.74 (m, 2H, H-morpholino), $1.30\left(\mathrm{t},{ }^{3} \mathrm{~J}_{\mathrm{HH}}=7.1 \mathrm{~Hz}, 3 \mathrm{H}, \mathrm{CH}_{3}\right.$ ). Anal. Calcd. for $\mathrm{C}_{8} \mathrm{H}_{14} \mathrm{~N}_{2} \mathrm{O}_{3} \mathrm{~S}(218.43)$ : C, 44.02; H, 6.46; N, 12.83\%. Found: C, 43.88; H, 6.32; N, 12.93\%.

Reaction of 2-(4-bromophenyl)-5-(4-chlorophenyl)-4-(3-bromo-4-morpholino-1-aza-1,3butadien-1-yl)-1,2,3-triazole $1 \mathrm{~b}$ with ethoxycarbonyl isothiocyanate. A solution of $1 \mathrm{~b}$ (280 $\mathrm{mg}, 0.5 \mathrm{mmol})$ in $\mathrm{CH}_{2} \mathrm{Cl}_{2}(5 \mathrm{ml})$ was stirred with ethoxycarbonyl isothiocyanate $(70 \mathrm{mg}, 63 \mu \mathrm{l}$, $0.5 \mathrm{mmol})$ at room temperature for 2 weeks. The solvent was evaporated, the residue was chromatographed on Silica gel with $\mathrm{CHCl}_{3}$ to give $25 \mathrm{mg}(11.9 \%)$ of pale yellow crystals of 2-(4bromophenyl)-5-(4-chlorophenyl)-4-(ethoxycarbonylamino)-1,2,3-triazole (28), mp 195-197 ${ }^{\circ} \mathrm{C}$ (diethyl ether). The compound was identical with that described above.

sym-Diethyl hydrazinedicarboxylate 34. A solution of $\mathbf{1 b}(280 \mathrm{mg}, 0.5 \mathrm{mmol})$ in a mixture of $\mathrm{CHCl}_{3}(5 \mathrm{ml})$ and acetonitrile $(5 \mathrm{ml})$ was refluxed with diethyl azodicarboxylate $(0.33 \mathrm{~g}, 0.3 \mathrm{ml}$, $1.9 \mathrm{mmol}$ ) for $50 \mathrm{~h}$. The solvent was evaporated and the residue was chromatographed on silica gel with $\mathrm{CHCl}_{3}$ as eluent to give traces of $\mathbf{2}$ (according to TLC) and sym-diethyl hydrazinedicarboxylate (34). White crystals, yield $24.2 \%, 80 \mathrm{mg}, \mathrm{mp} 130-132^{\circ} \mathrm{C}$ (diethyl ether) (Lit. $\left.{ }^{22} \mathrm{mp} 135^{\circ} \mathrm{C}\right) .{ }^{1} \mathrm{H}$ NMR $\left(\mathrm{CDCl}_{3}\right): \delta_{\mathrm{H}} 6.45\left(\mathrm{~s}, 2 \mathrm{H}, \mathrm{NH}_{2}\right), 4.22\left(\mathrm{q},{ }^{3} J_{\mathrm{HH}}=7.1 \mathrm{~Hz}, 4 \mathrm{H}, \mathrm{CH}_{2}\right), 1.28$ $\left(\mathrm{t},{ }^{3} J_{\mathrm{HH}}=7.1 \mathrm{~Hz}, 6 \mathrm{H}, \mathrm{CH}_{3}\right.$ ). Anal. Calcd for $\mathrm{C}_{6} \mathrm{H}_{12} \mathrm{~N}_{2} \mathrm{O}_{4} \times 0.5 \mathrm{H}_{2} \mathrm{O}$ (185.19): C, 38.91; H, 7.08; N, $15.13 \%$. Found: C, 38.72; H, 6.86; N, $15.39 \%$.

Dimethyl 4-\{N-[2-(4-bromophenyl)-4-(4-chlorophenyl)-1,2,3-triazol-5-yl]\}imino-formylpyridazine-3,6-di-carboxylate (34). A solution of $1 \mathbf{a}(120 \mathrm{mg}, 0.25 \mathrm{mmol})$ in dichloroethane (5 $\mathrm{ml})$ was stirred with $35(120 \mathrm{mg} 0.6 \mathrm{mmol})$ at room temperature for $2 \mathrm{~h}$. The precipitate was filtered off washed with dichloroethane $(1 \mathrm{ml})$ to give $78 \mathrm{mg}$ of yellow crystals. The mother liquor was chromatographed on silica gel with $\mathrm{CH}_{2} \mathrm{Cl}_{2}$-ethanol = 200:1 to give another quantity $(51 \mathrm{mg})$ of product. Altogether $129 \mathrm{mg}(91.5 \%)$ of pure product was obtained, $\mathrm{mp} 228-230^{\circ} \mathrm{C} .{ }^{1} \mathrm{H}$ NMR (DMSO- $\left.d_{6}\right): \delta_{\mathrm{H}} 9.60$ (s, 1H, H-imino), 8.82 (s, 1H, H-5), 8.10 (m, 2H, H-2',6'(4-Clphenyl)), 8.03 (m, 2H, H-2',6'(4-Br-phenyl)), 7.82 (m, 2H, H-3',5'(4-Br-phenyl)), 7.60 (m, 2H, H3',5'(4-Cl-phenyl)), 4.05 (s, 3H, OMe), 3.94 (s, 3H, OMe). ${ }^{13} \mathrm{C}$ NMR (DMSO-d $)$ ): $\delta_{\mathrm{C}} 164.88$, $163.55,159.57,153.02$, 151.92, 151.36, 142.16, 138.14, 134.51, 133.44, 133.08, 129.50, 129.28, 127.79, 127.71, 121.46, 120.75, 53.68, 53.66. Anal. Calcd for $\mathrm{C}_{23} \mathrm{H}_{16} \mathrm{BrClN}_{6} \mathrm{O}_{4}$ (555.80): C, 49.71; H, 2.90; N, 15.12\%. Found: C, 49.47; H, 2.77; N, $14.98 \%$.

\section{References}

$\dagger$ Present address: AMRI Hungary, Záhony u. 7, Budapest, H-1031, Hungary 
1. Fused azolium salts, part 22. For part 21 see: Bátori, S.; Gács-Baitz, E.; Bokotey, S.; Messmer, A. Tetrahedron 2003, 59, 4297.

2. Lloyd, D.; Mc Nab, H. Angew. Chem. 1976, 88, 496 and citation therein.

3. Knorr, R.; Zölch R.; Polborn, K. Heterocycles 1995, 40, 559.

4. Petrich, A. S.; Quan, Z.; Santiago, L. M.; Gupton, J. T.; Sikorski, J. A. Heterocycles 1995, $40,729$.

5. Brain, E. G.; Finar, I. L. Chem. Ber. 1958, 91, 2435.

6. Finar I. L.; Foster, T. J. Chem. Soc. (C) 1967, 1494.

7. (a) Balbiano, L. Gazzetta 1889, 19, 128. (b) Khan, M. A.; Mustafa, A. Pharmazie 1986, 41, 813.

8. Dieckmann, W.; Platz, L. Chem. Ber. 1904, 37, 4638.

9. Messmer, A.; Hajós, Gy.; Timári, G.; Gelléri, A. Monatsh. Chem. 1988, 119, 1121.

10. Béres, M.; Hajós, Gy.; Riedl, Zs.; Timári, G.; Messmer, A.; Holly, S.; Schantl, J. G. Tetrahedron 1997, 53, 9393.

11. Jutz, Ch.; Kirschner, A. F.; Wagner, R.-M. Chem. Ber. 1977, 110, 1259.

12. Schroth, W.; Peschel, J.; Zschunke, A. Z. Chem. 1969, 9, 110.

13. Stankovic, S.; D’hooghe, M.; Catak, S.; Eum, H.; Waroquier, M.; Van Speybroeck, V.; De Kimpe, N.; Ha, H.-J. Chem. Soc. Rev. 2012, doi 10.1039/c1cs15140a.

14. Métro, T.-X.; Duthion, B.; Cossy, J. Chem. Soc. Rev. 2010, 39, 89.

15. (a) Stankovic, S.; D'hooghe, M.; De Kimpe, N. Org. Biomol. Chem. 2010, 8, 4266. (b) Kim, Y.; Ha, H.-J.; Yun, S. Y.; Lee, W. K. Chem. Commun. 2008, 4363. (c) Yun, S. Y.; Catak, S.; Lee, W. K.; D’hooghe, M.; De Kimpe, N.; Van Speybroeck, V.; Waroquier, M.; Kim, Y.; Ha, H.-J., Chem. Commun. 2009, 2508. (d) Catak, S.; D’hooghe, M.; De Kimpe, N.; Waroquier, M.; Van Speybroeck, V. J. Org. Chem. 2010, 75, 885.

16. Timári, G.; Hajós, Gy.; Messmer, A.; Gelléri, A. Monatsh. Chem. 1988, 119, 1037.

17. Xu, X.; Li, X.; Ma, L.; Ye, N.; Weng, B. J. Am. Chem. Soc. 2008, 130, 14048.

18. Abbiati, G.; Cirrincione de Carvalho, A.; Rossi, E. Tetrahedron 2003, 59, 7397.

19. Pearson, M. S. M.; Robin, A.; Bourgougnon, N.; Meslin, J. C.; Deniaud, D. J. Org. Chem. 2003, 68, 8583.

20. El-Gazzar, A.-R. B. A.; Scholten, K.; Guo, Y.; Weißenbach, K.; Hitzler, M. G.; Roth, G.; Fischer, H.; Jochims, J. C. J. Chem. Soc. Perkin Trans. 1 1999, 1999.

21. Synthetic and analytical data given but no mp available: Linton, B. R.; Carr, A. J.; Orner, B. P.; Hamilton, A. D. J. Org. Chem. 2000, 65, 1566.

22. Müller, E. Chem. Ber. 1914, 47, 3001.

23. Esquivias, J.; Arrays, R. G.; Carretero, J. C. J. Am. Chem. Soc. 2007, 129, 1480.

24. Orth, R. E. J. Pharm. Sci. 1968, 57, 537.

25. Kumar, G. G.; Vikas, K.; Vinod, K. Res. J. Chem. Environ. 2011, 15, 90.

26. Bekhit, A. A.; Hymete, A.; Bekhit, A. El-D. A.; Damtew, A.; Aboul-Enein, H. Y. Mini Rev. Med. Chem. 2010, 10, 1014.

27. Martinez, A.; Castro, A.; Medina, M. Heterocycles 2007, 71, 1467. 
28. Yoon, J.-Y.; Lee, S.; Shin, H. Curr. Org. Chem. 2011, 15, 657.

29. Boehm, R.; Karow, Ch. Pharmazie 1981, 36, 243.

30. Piribi, I.; Buscemi, S. Curr. Bioactive Comp. 2010, 6, 208.

31. Kolb, H. C.; Sharpless, K. B. Drug Disc. Today 2003, 8, 1128.

32. Agalave, S. G.; Maujan, S. R.; Pore, V. S. Chem. Asian J. 2011, 6, 2696.

33. Mamidyala, S. K.; Finn, M. G. Chem. Soc. Rev. 2010, 39, 1252.

34. Jewetta, J. C.; Bertozzi, C. R. Chem. Soc. Rev. 2010, 39, 1272.

35. Baskin, J. M.; Bertozzi, C. R. Aldrichimica Acta 2010, 43, 15.

36. Asif, M.; Singh, A. Int. J. Chem. Tech. Res. 2010, 2, 1112.

37. Banerjee, P. S. Asian J. Chem. 2011, 23, 1905.

38. Asif, M.; Singh, A.; Siddiqui, A. A. Med. Chem. Res. 2012, doi 10.1007/s00044-011-9835-6.

39. Asif, M.; Singh, A.; Ratnakar, L. J. Pharm. Res. 2011, 4, 664.

40. Cignarella, G.; Barlocco, D. J. Het. Chem. 2002, 39, 545.

41. Lange's Handbook of Chemistry, Dean, J. A., Ed., McGraw-Hill Book Company, 1973. 